\title{
Analisis Jawaban Siswa Usia 6 sampai 8 tahun terhadap Pembelajaran Sains Kreatif
}

\author{
Ramdhan Witarsa ${ }^{1 凶}$, Dini Xena Dista ${ }^{2}$ \\ Pendidikan Guru Sekolah Dasar, Universitas Pahlawan Tuanku Tambusai \\ DOI: $10.31004 /$ obsesi.v4i1.288
}

\begin{abstract}
Abstrak
Tujuan penelitian dari artikel ini adalah untuk menganalisis jawaban-jawaban siswa sekolah dasar kelas rendah terhadap pertanyaan-pertanyaan yang diberikan guru saat pembelajaran sains kreatif yang dilakukan di kelas. Metode penelitian yang digunakan adalah metode penelitian deskriptif kuantitatif. Guru memberikan sejumlah pertanyaan mengenai sains, kemudian siswa merespon jawaban tersebut, dan kemudian dianalisis secara deskriptif kuantitatif. Pertanyaan-pertanyaan yang guru berikan berupa pertanyaan tertutup dan terbuka tergantung maksud dan tujuan pertanyaan tersebut diberikan. Hasil penelitian menunjukan bahwa jawaban-jawaban siswa sekolah dasar kelas rendah terhadap pembelajaran sains kreatif menunjukan jawaban-jawaban yang tergolong pada aspek-aspek kreatif. Kebaruan penelitian ini menunjukan bahwa aspek kreatif sudah nampak berkembang secara terstruktur pada siswa sekolah dasar kelas rendah. Pembelajaran sains kreatif perlu diterapkan sejak dini di sekolah-sekolah dasar agar kemampuan berpikir kreatif siswa berkembang dengan baik secara terstruktur.
\end{abstract}

Kata Kunci: kreatif; pembelajaran; sains; siswa kelas rendah.

\begin{abstract}
The research objective of this article is to analyze the answers of low grade primary school students to the questions given by the teacher while learning creative science conducted in class. The research method used is quantitative descriptive research method. The teacher gives a number of questions about science, then students respond to these answers, and then analyzed descriptively quantitatively. The questions that the teacher gives are closed and open questions depending on the purpose and purpose of the question given. The results showed that the answers of low grade elementary school students to creative science learning showed answers belonging to the creative aspects. The novelty of this study shows that the creative aspects appear to have developed structurally in low grade primary school students. Learning creative science needs to be applied early in elementary schools so that students' creative thinking skills develop well structured.
\end{abstract}

Keywords: creative; learnin; science; low grade students.

Copyright (c) 2019 Ramdhan Witarsa, Dini Xena Dista

$\triangle$ Corresponding author :

Email Address : drdadan19@gmail.com (: Jln. Tuanku Tambusai No.23 Bangkinang)

Received 9 September 2019, Accepted 27 September 2019, Published 28 September 2019 


\section{PENDAHULUAN}

Siswa-siswa sekolah dasar kelas rendah beberapa tahun ini (2014-2019) mengikuti pembelajaran apa adanya yang diberikan oleh gurunya di kelas. Pembelajaran yang dilakukan sebatas pada pembelajaran yang bersifat kognitif. Sementara siswa sekolah dasar kelas rendah yang baru memulai pendidikan formalnya tidak dikembangkan kreativitasnya melalui pembelajaran yang dilakukan guru, sehingga kreativitasnya tidak berkembang di masa yang akan datang. Kesulitan siswa dalam bersosial, berkomunikasi, dan memberikan jawaban saat diberikan pertanyaan oleh orang lain atau oleh gurunya, menjadi sebuah kendala tersendiri dalam pembelajaran.

Jawaban-jawaban siswa kelas rendah terhadap pertanyaan-pertanyaan yang diberikan guru memiliki peran penting dalam kegiatan pembelajaran. Sebagian besar guru cenderung menghabiskan $60 \%$ dari waktu pembelajaran mereka dengan memberikan-pertanyaanpertanyaan (Sullivan \& Lilburn, 2002).

(Yee, 2000) menyatakan bahwa beberapa penelitian menemukan bahwa pertanyaanpertanyaan guru mempengaruhi pertumbuhan pengetahuan konseptual siswa yang membantu kemajuan pemikiran siswa. Pertanyaan juga dapat membantu guru untuk beberapa hal sebagai berikut: untuk mengetahui apakah siswa mendengarkan dan memahami pembelajaran, untuk merangsang pemikiran siswa, untuk mengembangkan komunikasi antar siswa dan guru, dan untuk membantu siswa mencapai tujuan pendidikan (Shahrill, 2013).

Pertanyaan-pertanyaan guru memainkan peran yang cukup penting dalam mengendalikan lingkungan kelas dan menciptakan diskusi kelas (Ulleberg \& Solem, 2018). Peran-peran ini mengidentifikasi betapa pentingnya pertanyaan guru di kelas. Penelitian sebelumnya dilakukan untuk mengetahui interaksi antara guru dan siswa, tetapi masih ada beberapa daerah untuk penelitian tentang pertanyaan dan diskusi kelas (Zahra, Kusmayadi, \& Usodo, 2018). Oleh karena itu, penelitian mengenai pertanyaan-pertanyaan guru yang merangsang diskusi yang kaya masih perlu dianalisis lebih lanjut.

(Capraro, Capraro, \& Cifarelli, 2007) mengungkapkan bahwa berpikir perlu untuk menyediakan siswa kelas rendah dengan banyak pengalaman pemecahan masalah yang mencakup masalah tertutup dan terbuka. Namun, beberapa penelitian menemukan bahwa sebagian besar pertanyaan yang diberikan guru dalam pembelajaran merupakan pertanyaan tertutup yang hanya memiliki satu jawaban yang benar.

Guru diminta untuk mengajukan berbagai jenis pertanyaan untuk merangsang kreativitas sebagai salah satu standar dari kurikulum (Kwon, Park, \& Park, 2006). Mereka percaya bahwa pembelajaran sains harus menekankan kreativitas untuk memberikan kesempatan bagi siswa kelas rendah untuk mengembangkan berbagai solusi ketika menjawab pertanyaan. Meskipun kreativitas sangat penting dalam pembelajaran sains, masih dipertanyakan jenis kreativitas siswa kelas rendah di kelas. Oleh karena itu, masih menjadi masalah yang bisa dipelajari.

Guru harus mempertimbangkan bagaimana mereka harus mengajukan pertanyaan kepada siswa, mendorong siswa untuk memberikan jawaban mereka (Cotton, 2001). Guru juga dapat menanyakan pertanyaan lisan atau tertulis kepada individu atau kelompok siswa. Guru melakukan teknik waktu tunggu setelah mengajukan pertanyaan dimana guru memberikan waktu bagi siswa untuk mempertimbangkan tentang pertanyaan sebelum menjawab karena kadang-kadang siswa tidak dapat menjawab pertanyaan secara langsung.

Klasifikasikan pertanyaan guru ada sembilan kategori berdasarkan tujuan dan teknik pertanyaan guru, mereka akan sulit digunakan untuk analisis karena beberapa kategori memiliki arti yang serupa. (Yee, 2002) membagi jenis pertanyaan mengenai jumlah kemungkinan jawaban yang benar, menjadi dua jenis pertanyaan, pertanyaan tertutup dan terbuka. Pertanyaan tertutup hanya memiliki satu jawaban yang benar sementara pertanyaan terbuka memiliki banyak jawaban (merupakan ciri kreativitas). 
Klasifikasikan respon jawaban siswa terdiri dari kelas rendah ke dalam penjelasan, berbagi, pembenaran, tantangan, dan jawaban. Penjelasan berbeda dengan berbagi karena siswa diminta untuk menjelaskan jawaban atau strategi mereka. Pembenaran mengacu pada ketika siswa menguraikan penjelasan mereka, biasanya terjadi ketika menanggapi pertanyaan yang membutuhkan pembuktian. Tantangan diberikan kepada siswa sementara mereka mempertanyakan atau menantang jawabannya. Jika siswa memberikan jawaban atau tanggapan singkat, tanggapan ini akan disebut sebagai jawaban.

Tiga bagian kreativitas yang diteliti adalah kelancaran (jumlah jawaban yang berbeda), fleksibilitas (jumlah strategi untuk memecahkan pertanyaan), dan orisinalitas (berapa banyak jawaban dalam mengatur semua pertanyaan atau kekerapan jawaban). Pertanyaan terbuka efektif dalam mendorong kreativitas siswa kelas rendah karena pertanyaanpertanyaan ini memungkinkan siswa untuk menerapkan strategi mereka sendiri dalam menemukan jawaban beragam yang mungkin baru.

Berdasarkan latar belakang yang telah diungkapkan, peneliti bermaksud mencari jawaban untuk dua pertanyaan penelitian sebagai berikut: Bagaimana guru mengajukan pertanyaan-pertanyaan kepada siswa kelas rendah?; Kreativitas seperti apa yang diberikan melalui jawaban-jawaban siswa kelas rendah terhadap pertanyaan di kelas?

Batasan-batasan penelitian sebagai berikut: Penelitian ini dibatasi pada siswa sekolah dasar kelas rendah; Indikator yang diukur adalah jawaban-jawaban yang diberikan siswa saat pembelajaran sains berlangsung.

Tujuan dari penelitian ini adalah untuk mengetahui jawaban-jawaban yang diberikan siswa kelas rendah terhadap pertanyaan-pertanyaan yang diberikan guru saat pembelajaran sains dilakukan.

Target-target luaran penelitian sebagai berikut: Adanya instrumen yang valid dan reliabel untuk mengukur jawaban-jawaban yang diberikan siswa kelas rendah pada mata pelajaran sains; Data-data dan fakta saat kegiatan ini dilakukan bisa menjadi bahan kajian lanjutan untuk menulis karya ilmiah berikutnya dan bisa dipublikasikan pada jurnal nasional dan internasional; Sebagai bahan kajian untuk penelitian berikutnya.

\section{METODOLOGI}

Metode penelitian yang digunakan adalah metode penelitian deskrptif kuantitatif. Penelitian ini melibatkan seorang guru perempuan yang mengajar sains untuk siswa-siswa sekolah dasar kelas 1 sebanyak 36 siswa.

Data yang dikumpulkan menggunakan pedoman observasi dan wawancara. Pengamatan dilakukan untuk mengetahui cara guru memberikan pertanyaan, jenis pertanyaan, dan jawaban yang diberikan oleh siswa (Aziza, 2018).

Selama pengamatan, kegiatan pembelajaran sains kreatif di kelas dicatat, catatan juga diambil, dan contoh karya siswa kelas rendah dikumpulkan secara acak. Rekaman video pembelajaran ditranskripsi, kemudian peneliti melakukan wawancara berdasarkan tujuan penelitian dan masalah yang ditemukan saat pengamatan di kelas yang memerlukan klarifikasi (Balım, Çeliker, Türkoğuz, \& Kaça, 2013).

Proses wawancara melibatkan guru dan lima siswa untuk mengklarifikasi pengamatan yang telah dilakukan dan menganalisis seperti apa kreativitas sains siswa kelas rendah tersebut. Wawancara ini juga direkam dan ditranskrip (Fraenkel, Wallen, \& Hyun, 2012).

Peneliti memastikan bahwa data yang diperoleh tersebut valid dengan menerapkan ketepatan alat, proses, dan data (Leung, 2015). Peneliti juga tidak terlibat dalam proses pembelajaran sains kreatif dimana peneliti dapat mencegah interpretasi bias selama proses pengumpulan data.

Para peneliti sebelumnya (Chin, 2007) menggunakan metode serupa untuk menyelidiki kegiatan bertanya guru meskipun mereka memiliki tujuan penelitian yang berbeda. Peneliti harus memastikan konsistensi dari proses dan temuan penelitian mereka. Selama pengumpulan data, peneliti menerapkan pendekatan yang sama menggunakan 
rekaman suara dan kemudian menyalinnya dengan memutar perekam beberapa kali (Jacob \& Sam, 2008).

Lokasi penelitian yang digunakan adalah sekolah dasar SD Pahlawan di Bangkinang, Kabupaten Kampar, Provinsi Riau. Peubah yang diamati atau diukur dalam penelitian ini adalah jawaban-jawaban siswa kelas rendah yang diberikan selama pembelajaran sains kreatif dilakukan di kelas.

Model yang digunakan dalam penelitian ini adalah model pembelajaran sains kreatif menggunakan teknik tanya jawab. Data yang dikumpulkan dianalisis secara statistik menggunakan SPSS, diinterpretasikan menggunakan persentase, dan dideskripsikan. Tahapan penelitian digambarkan melalui bagan sebagai berikut:

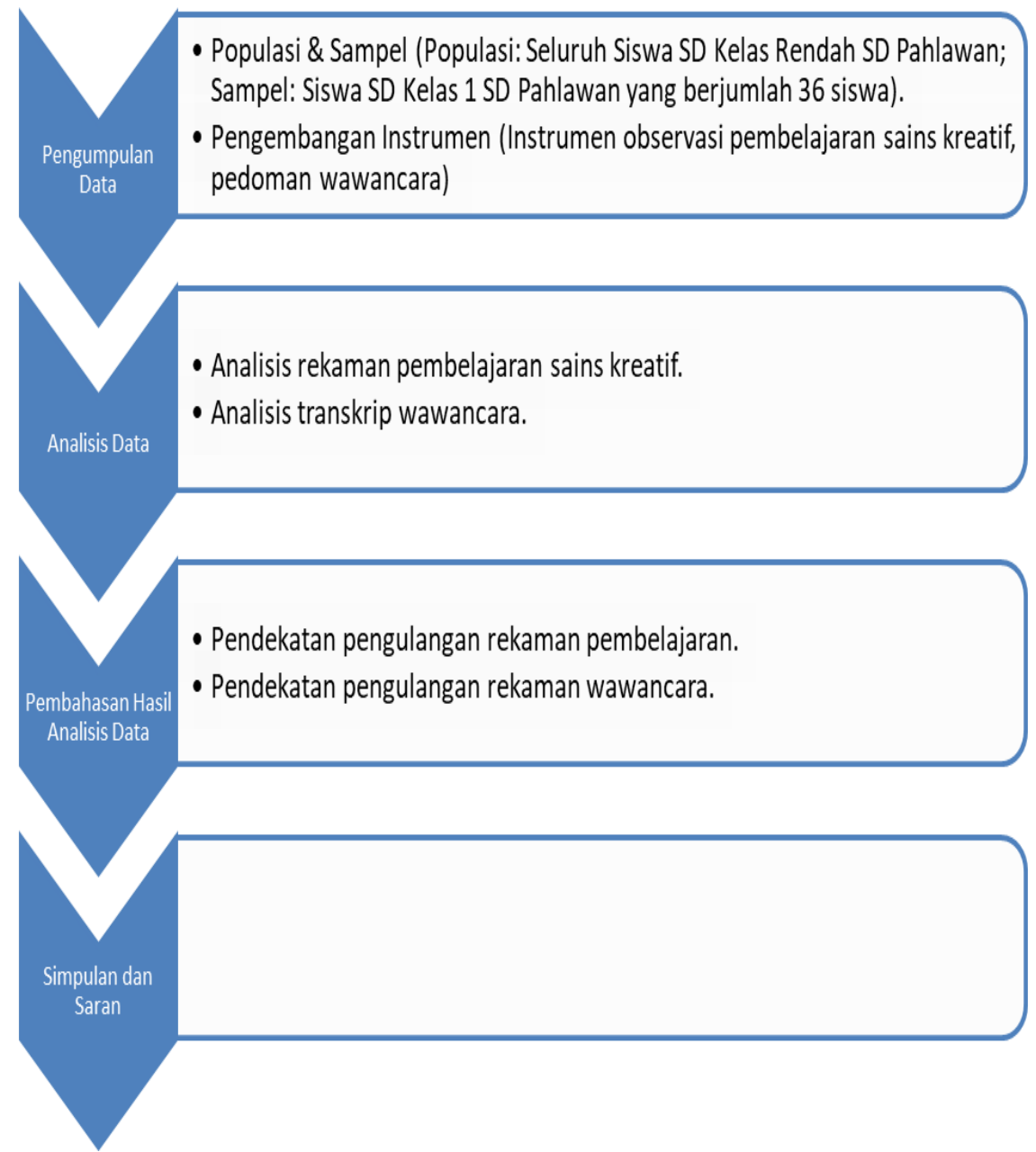

Bagan 1. Tahapan Penelitian

\section{HASIL DAN PEMBAHASAN}

Selama pembelajaran, guru mengajarkan tentang sains secara kreatif. Guru menyatakan bahwa dia menerapkan dua metode bertanya, meminta siswa kelas rendah secara lisan dan memberi tugas tertulis kepada siswa. Jika guru mengajar secara lisan mungkin pertanyaannya datang secara lisan. Guru pikir siswa tidak perlu memiliki lembar kerja setiap pelajaran sehingga lembar kerja hanya diberikan dari guru (Erdogan, 2011). Terkadang, pertanyaan itu tergantung pada subjek. Jika ingin jawaban ya atau tidak dari siswa, guru harus menggunakan pertanyaan tertutup (Dong, Clarke, Cao, Wang, \& Seah, 2019). 


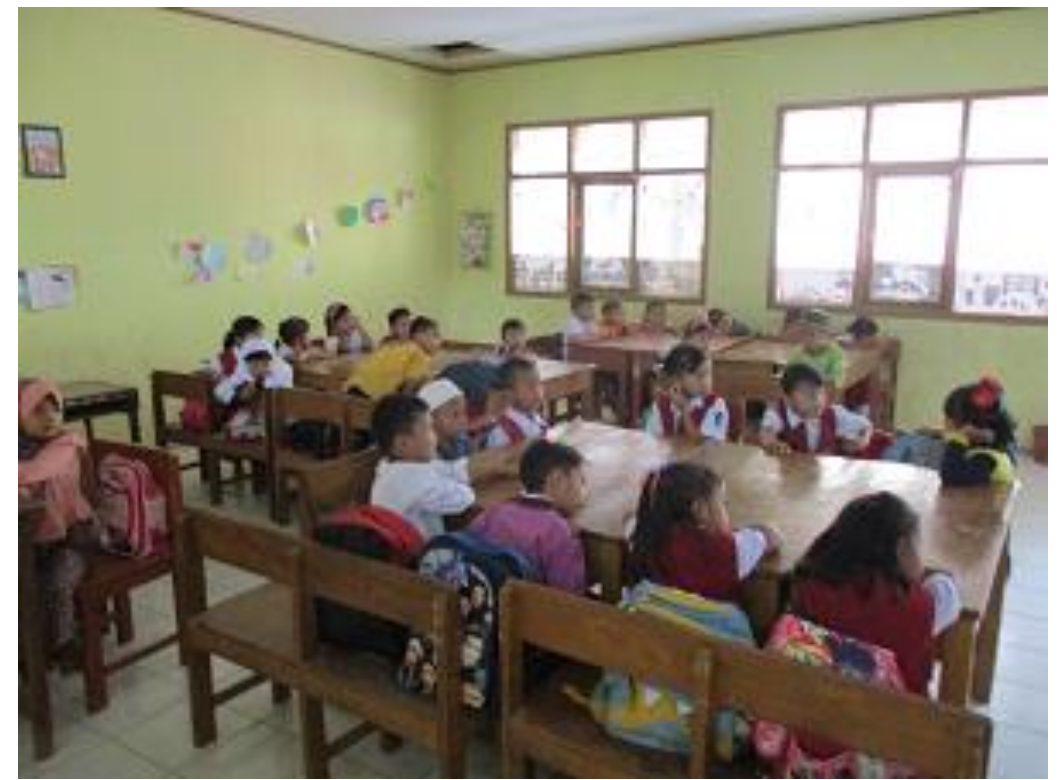

Gambar 1. Guru sedang Memberikan Pertanyaan kepada Siswa

Jika guru menginginkan pemahaman yang lebih dalam, guru menggunakan pertanyaan open-ended karena pertanyaan tersebut dapat membuat siswa berpikir dan menghasilkan ide-ide yang berbeda, dan dapat memperluas pembelajaran. Jadi, guru berpikir bahwa guru dapat melakukan keduanya. Pertanyaan lebih terbuka dapat diberikan terutama dalam pembelajaran sains kreatif karena guru ingin melihat hubungan antara konsep daripada hanya berpikir.

Ketika ditanya apa yang guru pikirkan tentang kebenaran jawaban siswa, guru mengatakan dia yakin tidak ada jawaban yang salah. Guru percaya hanya ada kesalahpahaman. Jadi, guru akan bekerja dengan jawaban siswa dan mencoba memberikan pertanyaan lanjutan kepada mereka untuk membuat mereka menyadari tentang kesalahan jawaban mereka dan mendapatkan jawaban yang benar. Pertanyaan yang bagus memungkinkan untuk kesalahan dan guru dapat membangun lebih banyak pertanyaan dari yang telah diberikan sebelumnya.

Guru dapat menanyakan berbagai jenis pertanyaan dengan menggunakan teknik yang berbeda, mengajukan banyak pertanyaan secara lisan. Guru juga menggunakan slide pada power point untuk mengilustrasikan pertanyaan, meminta siswa untuk menuliskan jawaban dalam buku latihan mereka (Arslan, 2006). Oleh karena itu, guru mengajukan pertanyaan baik lisan maupun tulisan.

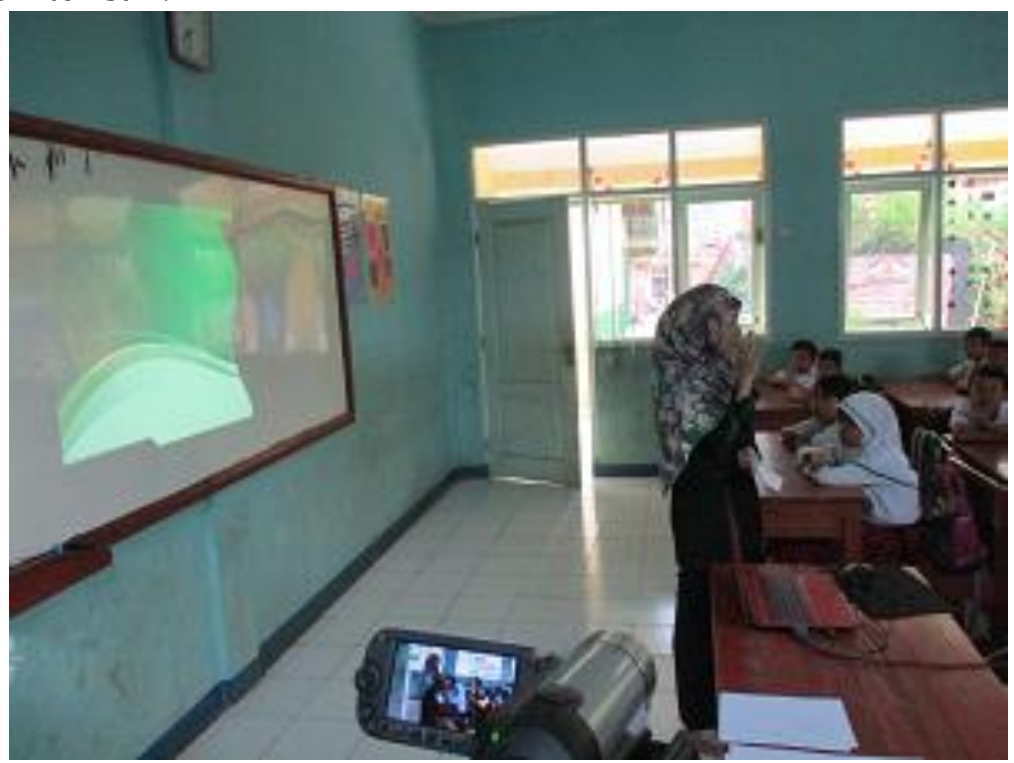

Gambar 2. Guru menggunakan Slide Power Point dalam Mengilustrasikan Pertanyaan 
Guru dapat melakukan teknik tunggu waktu, menunggu jawaban siswa. Guru juga dapat secara spontan mengembangkan pertanyaan tambahan berdasarkan jawaban siswa untuk mengeksplorasi ide-ide siswa kelas rendah lebih lanjut dan melibatkan seluruh kelas untuk memeriksa jawabannya. Melalui proses ini, para siswa dapat berbagi ide mereka satu sama lain dan menyelidiki apakah jawabannya benar atau tidak.

Dalam topik lain, sudut pandang guru tidak hanya mengajukan pertanyaan kepada seorang individu tetapi juga menginstruksikan siswa kelas rendah untuk mendiskusikan secara berpasangan untuk menjawab pertanyaan-pertanyaan yang diberikan (Dogruer, Isiksal, \& Koc, 2015).

Terdapat 30 jenis pertanyaan yang diberikan guru selama pembelajaran, 10 pertanyaan tentang sains dan sisanya tentang hubungan sains dan lingkungan. 20 pertanyaan ditutup, dan 10 pertanyaan merupakan pertanyaan terbuka. Guru menanyakan beberapa ekspresi yang berbeda dalam menanyakan pertanyaan tertutup atau terbuka. Dengan demikian, terlihat bahwa guru menanyakan pertanyaan tertutup dan terbuka selama pembelajaran sains kreatif. Dalam wawancara, guru menyatakan bahwa dia menanyakan pertanyaan berdasarkan subjek dan apa yang diinginkannya agar siswa memperolehnya. Dia akan mengajukan pertanyaan tertutup ketika menanyakan yang hanya memerlukan jawaban ya atau tidak.

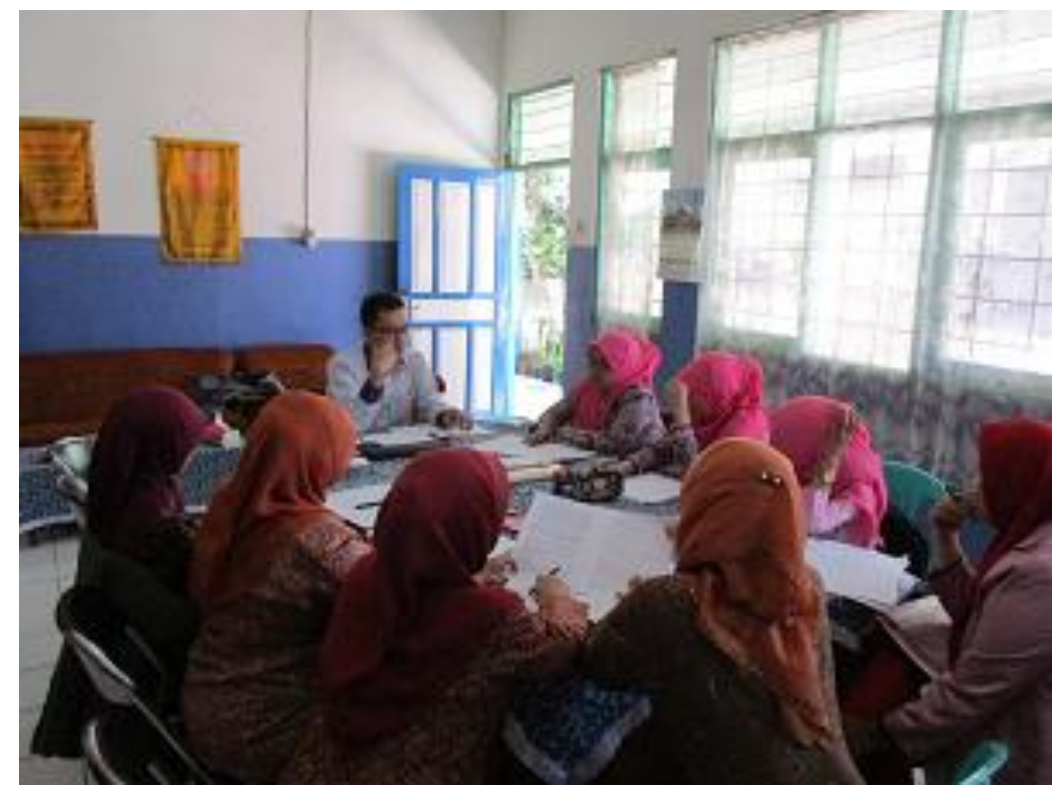

Gambar 3. Guru melakukan Wawancara dan Refleksi mengenai Pembelajaran Sains Kreatif

Guru akan mengajukan pertanyaan terbuka jika guru ingin mendorong siswa untuk berpikir secara mendalam dan menghubungkan konsep sains dengan banyak ide. Ketika mengajukan pertanyaan tertutup, guru mencoba mendorong siswa untuk menganalisis apa yang dimaksud dengan pertanyaan, misalnya, ketika guru bertanya tentang hubungan sains dan lingkungan yang mendorong siswa untuk berpikir tentang makna hubungan sains dan lingkungan.

Lebih jauh lagi, guru mengajukan siswa masalah yang merupakan salah satu jenis pertanyaan terbuka, sebuah masalah terbuka, dimana guru meminta siswa untuk membuat pertanyaan mereka sendiri berdasarkan pernyataan yang guru berikan. Dari masalah terbuka ini, guru berhasil mengangkat jawaban yang berbeda dari siswa. Guru juga mendorong siswa untuk menganalisis kesalahan jawaban teman-teman sekelas mereka dengan bertanya apakah itu benar.

Siswa kelas rendah dapat belajar untuk menyelidiki kebenaran jawaban. Selain itu, guru mengembangkan keterampilan komunikasi dan penalaran siswa dengan bertanya dari mana asalnya, bagaimana, dan mengapa. 
Terdapat beberapa jawaban secara lisan yang diberikan siswa kelas rendah selama pembelajaran sains kreatif. Jawaban-jawaban ini lebih dari jumlah pertanyaan yang diminta oleh guru karena beberapa pertanyaan terbuka menghasilkan banyak jawaban dari siswa. Dari menganalisis transkrip dari keseluruhan observasi, para siswa memberikan jawaban yang dikategorikan ke dalam 15 penjelasan, 3 pembenaran dan 50 jawaban singkat.

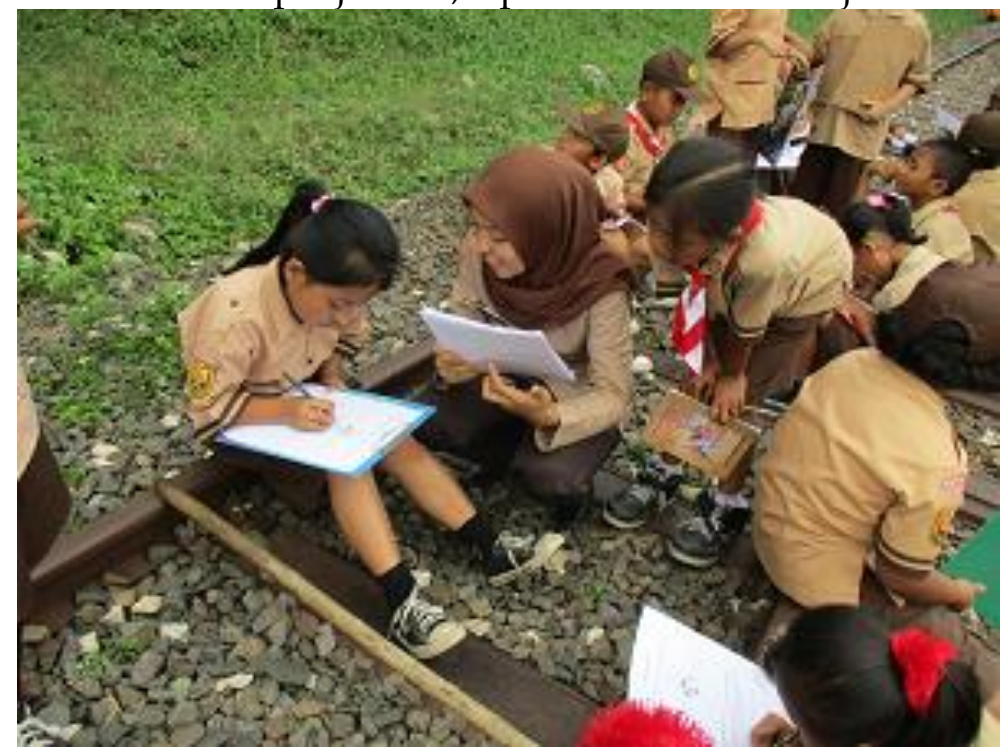

Gambar 4. Guru melakukan Wawancara dengan Siswa saat Pembelajaran Sains Kreatif

Sebagian besar siswa kelas rendah menjelaskan alasan dibalik jawaban mereka ketika menghadapi pertanyaan mengapa dan bagaimana serta memberikan jawaban singkat ketika guru memberikan pertanyaan ya atau tidak yang merupakan pertanyaan tertutup. Instruksi guru untuk membuat pernyataan berdasarkan pertanyaan dapat mendorong pembenaran jawaban siswa.

Kreativitas sains siswa yang berkaitan dengan kelancaran, fleksibilitas, dan orisinalitas dapat dilihat dari jawaban-jawaban siswa untuk pertanyaan terbuka. Terdapat sepuluh jawaban berbeda (kefasihan) yang diberikan siswa dimana guru memuji tiga jawaban (orisinalitas). Sebagian besar siswa menjawab dengan satu operasi dasar. Satu siswa mengajukan pertanyaan menggunakan dua operasi dasar (fleksibilitas).

Jawaban-jawaban siswa untuk tugas menunjukkan beberapa kelancaran. Untuk ide sains (fleksibilitas), sebagian besar siswa diasumsikan mereka berbeda dengan mempertimbangkan jawaban-jawaban sainsnya. Tiga siswa lainnya berpikir bahwa sains ilmu yang jelas. Namun, mereka menemui kebingungan sehingga mereka menganggap jawaban-jawaban mereka mirip.

Keaslian jawaban siswa tersebut tidak dapat ditentukan karena peneliti tidak memiliki jawaban perbandingan yang cukup untuk semua siswa di kelas. Meskipun siswa diminta langsung untuk memberikan jawaban dari sudut pandang yang berbeda dalam wawancara, kebanyakan siswa tetap memberikan jawaban yang hampir sama.

Guru dalam penelitian ini menghabiskan sebagian besar pembelajaran sains kreatif dengan mengajukan pertanyaan secara lisan. Apakah itu lebih baik bagi siswa masih tidak dapat dilihat secara langsung karena guru memiliki tujuan dan alasan mengapa dia melakukannya. Guru terlihat berusaha melakukan pertanyaan efektif untuk pembelajaran sains kreatif dengan mengajukan pertanyaan tertutup dan terbuka (McCarthy, Sithole, McCarthy, Cho, \& Gyan, 2016).

Pertanyaan tertutup membuat siswa menjawab dengan benar atau salah karena pertanyaan-pertanyaan itu memiliki jawaban yang tepat. Namun, guru tidak menggunakan pertanyaan terbuka hanya untuk memeriksa kebenaran jawaban, tetapi lebih fokus pada pengembangan komunikasi siswa, ide-ide sains, penalaran, dan keterampilan pemecahan masalah. Oleh karena itu, jawaban yang benar dan salah adalah penting bagi guru. 
Hasil penelitian ini menemukan bahwa guru tidak mencari kebenaran jawaban siswa selama pembelajaran sains kreatif. Namun, pemikiran guru ini harus diselidiki lebih lanjut di masa depan karena guru mungkin peduli dengan kebenaran jawaban dalam pembelajaran yang berbeda berdasarkan pada tujuan pembelajarannya.

Pertanyaan terbuka tampaknya memupuk kreativitas sains siswa, tetapi untuk mengevaluasi kreativitas sains siswa kelas rendah, guru menghadapi kesulitan terutama mencari keaslian ide-ide siswa. Kategori ide orisinil mungkin berbeda untuk guru yang berbeda karena pengalaman pribadi dan penilaian mereka terhadap ide tersebut.

Pertanyaan terbuka yang mendorong siswa untuk menghasilkan banyak jawaban juga menantang para guru untuk berpikir cepat apa yang harus mereka lakukan untuk menanggapi jawaban yang tidak terduga. Kadang-kadang, guru juga perlu memberikan pertanyaan tambahan untuk mendorong siswa untuk berpikir lebih jauh tentang jawaban mereka, terutama ketika mereka memiliki kesalahpahaman tentang pertanyaan.

\section{KESIMPULAN}

Guru memiliki pertimbangan sendiri dalam mengajukan pertanyaan, sehingga apa yang telah dilakukan guru dalam penelitian ini mungkin berbeda dengan guru lain. Guru menentukan jenis pertanyaan yang ingin mereka tanyakan berdasarkan tujuan pembelajaran mereka. Pertanyaan terbuka dapat digunakan oleh guru tidak hanya untuk menghasilkan kreativitas sains, tetapi juga mengembangkan pertanyaan tambahan untuk merangsang pemikiran siswa dan menganalisis kesalahpahaman siswa lebih lanjut.

\section{UCAPAN TERIMAKASIH}

Dengan segala hormat dan kerendahan hati, tim penulis memanjatkan puji syukur kehadirat Allah SWT atas segala rahmat dan karunia-Nya, sehingga tim penulis dapat menyelesaikan artikel ilmiah ini. Pembuatan artikel ilmiah ini, tim penulis mendapatkan arahan, bantuan, dan bimbingan yang sangat berharga dari berbagai pihak. Pada kesempatan ini, tim penulis mengucapkan terima kasih yang sebesar-besarnya kepada teman-teman satu tim penelitian, sekolah dasar tempat penelitian ini dilakukan, serta tim pengelola dan tim reviewer artikel jurnal yang telah meluangkan waktu dan kesempatannya untuk memberikan kesempatan dan arahan sehingga artikel ini dapat dipublikasikan.

\section{DAFTAR PUSTAKA}

Arslan, M. (2006). The Role of Questioning in the Classroom. Gaziosmanpasa University Faculty of Education, 2, 81-103.

Aziza, M. (2018). An analysis of a teacher's questioning related to students' responses and mathematical creativity in an elementary school in the UK. International Electronic Journal of Elementary Education, 10(4), 475-487. https://doi.org/10.26822/iejee.2018438138

Balım, A. G., Çeliker, H. D., Türkoğuz, S., \& Kaça, S. (2013). The Effect of Reflections of Science on Nature Project on Students ' Science Process Skills. Journal of Research in Education and Teaching, 2(16), 149-157.

Capraro, M. M., Capraro, R. M., \& Cifarelli, V. V. (2007). What are students thinking as they solve open-ended mathematics problems? Ninth International Conference of Mathematics Education in a Global Community, (October), 124-128.

Chin, C. (2007). Teacher Questioning in Science Classrooms: Approaches that Stimulate Productive Thinking. Journal of Research in Science Teaching, 39(2), 157-162. https://doi.org/10.1002/tea.20171.

Cotton, K. (2001). Classroom Questioning. Federation Proceedings, 36(3).

Dogruer, S. S., Isiksal, M., \& Koc, Y. (2015). A Case Study on Mathematical Classroom Discourse in a Fifth Grade Classroom Beşinci Sınıf Matematiksel Söylem Üzerine Bir 
Durum Çalışması. Journal of Social Sciences, 14(1), 299-322. Retrieved from https:// doi.org/10.21547/jss.256779

Dong, L., Clarke, D., Cao, Y., Wang, L., \& Seah, W. T. (2019). Teacher questioning practices over a sequence of consecutive lessons: A case study of two mathematics teachers. Sustainability (Switzerland), 11(1). https:/ / doi.org/10.3390/su11010139

Erdogan, M. (2011). The Effects of Ecology-Based Summer Nature Education Program on Primary School Students' Environmental Knowledge, Environmental Affect, and Responsible Environmental Behavior. 11(4), 2233-2237.

Fraenkel, J. R., Wallen, N. E., \& Hyun, H. H. (2012). How to Design and Evaluate Research in Education.

Jacob, S. M., \& Sam, H. K. (2008). Measuring Critical thinking in Problem Solving through Online Discussion Forums in First Year University Mathematics. Lecture Notes in Engineering and Computer Science, I, 19-21.

Kwon, O. N., Park, J. S., \& Park, J. H. (2006). Cultivating divergent thinking in mathematics through an open-ended approach. Asia Pacific Education Review, 7(1), 51-61. https:// doi.org/10.1007/BF03036784

Leung, L. (2015). Validity, reliability, and generalizability in qualitative research. Journal of Family Medicine and Primary Care, 4(3), 324. https://doi.org/10.4103/22494863.161306

McCarthy, P., Sithole, A., McCarthy, P., Cho, J., \& Gyan, E. (2016). Teacher questioning strategies in mathematical classroom discourse: A case study of two grade eight teachers in Tennessee, USA. Journal of Education and Practice, 7(21), 80-89.

Shahrill, M. (2013). Review of effective teacher questioning in mathematics classrooms. International Journal of Humanities and Social Science, 3(17), 224-231.

Sullivan, P., \& Lilburn, P. (2002). Good Questions for Math Teaching: Why Ask Them and What to Ask, Grades K-6. In Teaching Children Mathematics (Vol. 10). Retrieved from http:/ / search.proquest.com/docview / 214135816? accountid=8579

Ulleberg, I., \& Solem, I. H. (2018). Which questions should be asked in classroom talk in mathematics? Presentation and discussion of a questioning model. Acta Didactica Norge, 12(1), 21. https:/ / doi.org/10.5617/adno.5607

Yee, F. P. (2000). Open-ended Problems for Higher-Order Thinking in Mathematics. Teaching \& Learning, 20(2), 49-57. Retrieved from http://repository.nie.edu.sg/jspui/bitstream/10497/365/1/TL-20-2-49.pdf, tgl 15 Nov 2013

Yee, F. P. (2002). Using Short Open-ended Mathematics Questions to Promote Thinking and Understanding. Proceedings of the 4 Th International Conference on The Humanistic Renaissance in Mathematics Education, Palermo, Italy., 135-140.

Zahra, L., Kusmayadi, T. A., \& Usodo, B. (2018). The kinds of questions asked by novice teachers in learning mathematics. Journal of Physics: Conference Series, 1013(1). https:// doi.org/10.1088/1742-6596/1013/1/012124 